\title{
THE ANATOMY OF PENSION FRAUD IN NIGERIA: ITS MOTIVES, THE MANAGEMENT AND FUTURE OF THE NIGERIAN PENSION SCHEME
}

\author{
Amaka E. Agbata', Chizoba M. Ekwueme' and Edirin Jeroh*2 \\ 'Department of Accountancy, Nnamdi Azikiwe University, Awka, Anambra State, Nigeria \\ 2Department of Accounting, Delta State University, Abraka, Delta State, Nigeria
}

The study determined how the administration of the Pension Scheme could be perked up in Nigeria through effective management that would reduce fraudulent practices apparent in the scheme. By following the precept of library research via the survey design, a 5-point Likert Scale questionnaire was designed to educe primary information about pension matters from a sample of 435 knowledgeable respondents. The collected data were presented and analyzed. Three hypotheses were formulated and tested based on Multiple Regression Analysis models with the aid of Minitab version 17. The findings show that, despite the provisions of the Act (the Pension Reform Act - PRA), intents for committing Pension Fraud have not reduced to a significant extent. Also, the accumulated assets of pension funds have not been adequately diversified into profitable investment alternatives. Therefore, we recommend that, among other things, amendments should concertedly be made to the PRA to at least discourage acts of pension frauds by instituting severe punitive measures for culprits, while simultaneously inculcating moral ethics among public servants in Nigeria.

Keywords: National Pension Commission, pension funds, pension fraud, Pension Reform Act, pension fund administrators, pension fund custodians

JEL Classification: G23, G28, $\mathrm{H}_{55}$

\section{INTRODUCTION}

The development of a viable and workable pension scheme in Nigeria has always been clamored not only by pensioners, but also by notable stakeholders and the general populace. This is the reason why the

* Correspondence to: E. Jeroh, Department of Accounting, Delta State University, Abraka, Delta State, Nigeria; e-mail: jeroh4laffs@gmail.com
Government of Nigeria decided to adopt the structure of the Chilean-Styled Pension Scheme as a way of dealing with the challenges posed by the previously adopted defined benefit scheme. According to Y. Demola (2008), this decision of the Federal Government of Nigeria has changed the funding structure of the pension scheme in the country from the usual Pay-As-You-Go (PAYG) to the Contributory Pension Scheme (CPS). 
The CPS came in force through the enactment of the Pension Reform Act (PRA) of 2004, which again was revised by the PRA, 2014 (Onyeonoru, Matthew \& David, 2013; Adeniji, Akinnusi, Falola \& Ohunakin, 2017). G. Mesike and A. Ibiwoye (2012) avers that the design of the CPS is such that the associated risk/burden of retirement financing was shifted from entirely that of the Government to that majorly of individuals. Experts believe that the CPS is presumably better than the old pension scheme, except for the incidence of fraud and mismanagement. No doubt, various models and pension scams have evolved over the years given the changes evident in pensions and their attendant schemes (The Pension Regulators, 2015).

In fact, the argument has been that an insight into the pension affairs of some Ministries, Departments, and Agencies (MDAs) clearly indicates the evidence of the pension fraud that has negatively affected the success of the CPS. The perpetrators of such pension frauds are partly the management, upon whom such funds have been entrusted. Their motivation for indulging in a pension scam may not be different from the same motivation identified with the other forms of frauds. K. Tasker (2012) observes that pension fraudsters feel that they have a need which is either a real financial need or a perceived need, such as a desire for material goods. While fraud and/or pension scams continue with a varying and alarming magnitude, it is believed that, if uncontrolled, their effect on the overall success of the CPS will be detrimental. It is on the basis of the said that this study attempts to address the issues of pension fraud and how the strategic management of pension funds and possible fraud reduction could guarantee a viable and formidable scheme in the country. Specifically, this study attempts to:

- determine the effect of the Pension Reform Act (PRA) and its provisions on the motive for committing a pension fraud in Nigeria;

- measure the degree of the diversification of the Pension Fund Assets (PFA) into profitable investment opportunities;

- ascertain whether the anti-fraud measures provided by the PRA are effective in significantly reducing pension fraud in Nigeria.
Given the specific goals of this study, the following hypotheses were designed and subsequently tested:

Hypothesis One:

$\mathrm{H}_{\mathrm{O} 1}$ : The provisions of the PRA have not reduced to a significant extent the motive for perpetrating a pension fraud in Nigeria.

$\mathrm{H}_{\mathrm{A1}}$ : The provisions of the PRA have reduced to a significant extent the motive for perpetrating a pension fraud in Nigeria.

Hypothesis Two:

$\mathrm{H}_{\mathrm{O} 2}$ : PFAs are not adequately diversified into profitable investment opportunities.

$\mathrm{H}_{\mathrm{A} 2}$ : PFAs are adequately diversified into profitable investment opportunities.

Hypothesis Three:

$\mathrm{H}_{\mathrm{O} 3}$ : The anti-fraud measures provided by the PRA are not effective in significantly reducing pension fraud in Nigeria.

$\mathrm{H}_{\mathrm{A} 3}$ : The anti-fraud measures provided by the PRA are effective in significantly reducing pension fraud in Nigeria.

Given the aforementioned, this study relies on a survey design to generate relevant data for the analytical purpose; and the testing of the hypotheses is based on the multiple regression technique via Minitab 17.0. The remaining part of this paper deals with a conceptual and literature review, the anatomy and overview of the pension fraud/pension scam in Nigeria, the theoretical framework, an empirical review, the methods employed in the study, the results, the findings and the discussion, whereas the concluding part presents the recommendations.

\section{CONCEPTUAL AND LITERATURE REVIEW}

\section{The Meaning of "Pension"}

The word "pension" has majorly occupied the minds of researchers and public/civil servants in 
Nigeria. According to J. O. Odia and A. E. Okoye (2012), a pension occurs in a system where persons pay into identified schemes (the pension scheme) the proportions of their earnings/entitlements during their years of active service/work life. Such contributions provide earned income (or a pension) on retirement. In his definition, F. O. Ogwumike (2008) affirms that pensions are regular payments by employers to their respective employees after retirement, which usually is expected to continue till the death of such employees. According to T. M. Fapohunda (2013), a pension is the amount jointly set aside by both employers and their employees so as to ensure that workers are not financially stranded in their old age (i.e. after retirement). There are instances where pensions are payable to pensioners' next of kin subsequent to the pensioners' death, for an identified time frame though.

Similarly, O. I. Eme, O. A. Uche and I. B. Uche (2014a) see a pension as periodic income or annuity payments made at or after the retirement of the employees who may have become eligible for such benefits through their respective age, earnings and/or services. It is in view of these definitions that the Auditing Practices Board - APB (2011) categorized pension schemes into two main types: Occupational Pension Schemes (OPS) and Personal Pension Schemes (PPS). The OPSs are the schemes run by employers for the benefit of their employees, and, from an employee's viewpoint, are linked with employment; on the other hand, however, the PPSs are the schemes or individual arrangements intentionally designed by individuals. The APB (2011) further sub-divided the OPS's into three viz: Defined Benefit (or Earnings Related) Schemes, Defined Contribution (or Money Purchase) Schemes, and Hybrid Schemes. According to the APB, the Defined Contribution Pension Scheme refers to any pension scheme whose arrangement is such that an individual member's benefit would basically be determined with reference to the contributions paid into the scheme by such a member, and increased or decreased over time by an amount that succinctly reflects investment return on those contributions. The applicable CPS in Nigeria is a form of this type of scheme.

\section{The Anatomy of Pension Fraud}

Fraud connotes all deliberate acts designed to deceitfully and intentionally extort, distort, omit, misrepresent or conceal material facts for personal gains. It is what E. I. Okoye (2016) defined as an enemy to productivity. Fraud also refers to intentional acts designed to pervert the truth and take possession of the financial benefits and resources that belong to others or the inducement of parties to part with their valuables, belongings, legal rights and financial resources (Vasiu, Warren \& Mackay, 2003; Okoye \& Akenbor, 2009; Okoye, 2016). Explicitly, fraud connotes all multifarious channels of human ingenuity designed to intentionally obtain advantage over others through falsehood, tricks, concealment, deception, dissemblance and the containment of the truth deployed to cheat others (Okoye, Okafor \& Ijeoma, 2009; Nenyiaba \& Okoye, 2015). Fraud is usually employed with the intent of dishonesty aimed at depriving others from their rights to properties, financial resources and the like, thus making it a crime to humanity and punishable by laws when perpetrators are found culpable.

Owing to growth in pension funds over time, in addition to the multiplicity of complaints about retirees' accrued and unpaid pensions in different states of the federation, a lot of concerns have been raised and stakeholders have wondered continuously about what may probably have led to situations where after retirement the pensioners' entitlements remained unpaid over a number of years. Experts (Omah, Anifowose \& Ogundina, 2013; Nweke, 2015) have argued that fraud seems to be prevalent in the administration and management processes of the operational pension schemes in the country over the years. In his study, K. B. Olayinka (2010) notes that some risks are associated with pension schemes, their management and administration. Such risks may occur either in the short or long run. Prominent among the several forms of the risks associated with pensions are believed to be related to the management of pension funds and may be in the guise of the poor management of the PFAs, misappropriation and other forms of corrupt practices. 
A. Owojiri (2008) states that in the administration of a PF the ability of individual managers to identify and manage all identified associated risks will determine the level of effectiveness and efficiency in the operation of PFs. In line with this, E. Davis (1993) argues that a prudent diversification and indexation of the accumulated PFs, both in the foreign and the domestic markets, appear to be important in reducing any risks associated with PFs.

Additionally, T. M. Fapohunda (2013) believes that a viable investment of PFs will ensure a prompt and regular payment of retirees' and pensioners' entitlements. Similarly, good investment decisions will reduce the embezzlement and/or mismanagement of PFs by fraudsters or incompetent administrators of such funds.

However, given the belief that the creation of regulatory bodies would help in establishing ethical standards and reduce fraud in the management of PFs and other related matters, the Federal Government of Nigeria established the Economic and Financial Crimes Commission (EFCC) in 2003. Sadly, the coming of the EFCC neither put an end to nor reduced the existence of fraud in Nigeria, especially not so in the pension industry. Also, despite the several provisions and anti-fraud measures of the Act of 2004 (PRA, 2004) and its subsequent revision (PRA, 2014) with the main aim of protecting $P F$ assets the effective functioning of Nigeria's contributory pension scheme to date is yet to be guaranteed. In their study, S. R. Sipe, C. T. Metrejean and W. Donaldson (2015) state that, although the proper underlying framework for preventing and detecting pension fraud exists, there is yet a need for regulators to increase their efforts. Undoubtedly, numerous scandals have trailed Nigeria's pension scheme in recent times, so the need for the proper and efficient management of such a scheme to at least prevent further pension scams/ frauds cannot be overemphasized (Fapohunda, 2013).

\section{An Overview of Pension Fraud in Nigeria}

Nigeria has no doubt witnessed the notable and alarming cases of the outrageous acts of fraud that have led to multiple litigations, along with the arrest of several public office holders. The most alarming of them all is the highly canvassed "MAINAGATE". Noteworthy is the fact that prior to the alleged pension fraud of A. A. Maina, several other cases had surfaced on the front pages of national dailies since 2005. Succinctly, over N273 billion have been looted through pension scams in Nigeria between 2005 and 2011. According to E. Akinkuotu and I. Onuba (2016), the Nigerian anti-graft agency (EFCC) arrested a N. Mayshak with her 3 accomplices (P. Iyogun, Y. Youssoufou and R. Imonikhe) over a N2.5 billion fraud. Investigations according to the EFCC revealed that N. Mayshak, who was the Director General (DG) of the Pension Transitional Arrangement Directorate (PTAD), had misappropriated approximately N2 billion from the balances of sums in the pensions' accounts of different government establishments/ parastatals, which, among others, included the Nigeria Prisons, the Nigerian Custom and the Immigration Services, respectively. Additionally, a take-off grant of about N500 million intended for the PTAD was said to have been embezzled by the DG of the PTAD through a procurement fraud within her 3-year tenure.

In another streak, I. Omah, A. D. Anifowose and J. A. Ogundina (2013) highlight the menace of pension fraud in the country, which they see as the concomitant debacle given the brigade of the enlisted ghost pensioners that misrepresented genuine pensioners for the purpose of siphoning the pension funds in Nigeria over the years. Several reports of the EFCC had revealed the involvement of highly placed government functionaries in multiple embezzlements and pension scams. There are cases where the directors, deputy directors, heads of service, and even clerks, drivers and domestic staff of some of these government functionaries masterminded the diversion and lodgment of billions of pension funds through illegal bank accounts.

Interestingly, the Government had to set up the Pension Reform Task Team (PRTT) headed by A. A. Maina. At its onset, the PRTT uncovered the cases of pension scams, and working closely with the EFCC, efforts were made to recover some of the loots from various pension fund accounts. However, around mid-2010, there were indications that even the PRTT themselves had become fraudulent by having partaken in the squandering of over $\mathrm{N} 2$ billion, 
allegedly spent on obtaining the biometrics of the pensioners of the office of the Federation's Head of Service. As of 2011, other revelations indicated that the head of the PRTT (A. A. Maina) had been accused and indicted of awarding phony contracts and questionable spending binge (Omah, Anifowose \& Ogundina, 2013).

As noted by allAfrica (2012), reports from various committees set up to investigate the allegations against A. A. Maina and his PRTT further revealed that $\$ 1.6$ billion had been spent as the running cost for police pensions, whereas the amount appropriated for that purpose was $₫ 80$ million. Also, $₫ 830.8$ million was purported to have been spent to pay the pensions for June 2010 through the issuance of cheques rather than via the agreed e-payment system. There were allegations of the dubious and questionable enrolment of retirees in the pensioner payroll. Additionally, about $\$ 234$ million was spent on pensioners' biometrics, which was completed about $90 \%$ at that point; yet, no files were created, no document or data were made available as a piece of evidence for the captured pensioners to that effect. Again, without resort to the country's Embassy/High Commission, about $\mathrm{N17}$ million was said to have been spent on further biometrics and the verification of the pensioners residing outside the country (Pensioners in Diaspora - PID), whereas the available records reveal that as at that time, the so-called PIDs were not up to 30 persons.

U. Awom (2012) disclosed that the further reports of the Senate's ad-hoc committee set up to probe the management/administration of Nigeria's pension funds were revealing. There were indications of massive fraud and dubious collaborations intentionally designed to loot billions of naira. A further observation was that banks were handy collaborators in the unauthorized and illicit opening of the Government's accounts, changing/amending the existing signatories, transferring funds, depositing the Government's funds and the copious deprivation of financial transactions. Specifically, the same A. A. Maina that was commissioned to protect the pension funds was found to be deeply involved in the theft, confiscation, diversion and malicious spending binge of the pension funds. To perfect his ordeal, O. Agbedo (2017) reported that A. A. Maina had been purported to have used a number of staff and members of his team (PRTT) along with their associates and contractors to unethically receive payments for the biometric enrolment and the nonexistent contracts. The sums had also been paid and received for inflated contracts, only to ultimately be remitted to A. A. Maina, based on prior agreements and arrangements.

Through a complex web, A. A. Maina was accused of having laundered billions of naira along with his family members, account officers, associates and other corporate entities/contractors. In a letter of EFCC addressed to the office of the Attorney General of The Federation (AGF), the PRTT under the leadership of A. A. Maina spent a whooping sum of N5,761,150,608.44 on the alleged fictitious contracts, in addition to the N829,902,260.40 paid to ghost workers. Additionally, about N1,365,821,942.91 was looted under the auspices of collective allowances, whereas N4,192,825,310.99 was said to have been stolen under the guise of payments to the Pension Boards of various states. As noted by O. Agbedo (2017), the above sums are not inclusive of the N2,290,593,322.35 claimed to have been paid to the National Union of Pensioners and the N253,390,300 paid to the Association of Federal Public Service Retirees without a clear piece of evidence of the payments and the receipts. Given these and other indictments, A. A. Maina was removed and suspended from office, and a series of investigations, along with those of the other suspects, have been launched into his activities by concerned and relevant agencies.

\section{Fraud Perpetrated Against the Pension Scheme}

According to the KPMG (2005), the typical examples of frauds perpetrated against the pension scheme include: Beneficial Fraud - This is where the members of the scheme or their relatives claim or continue to benefit beyond their entitlement; Third Party Fraud This includes a theft from the scheme's bank accounts by the presentation of altered or false cheques; Trustee 
Fraud - Trustees themselves steal from the scheme or misuse its assets; Staff Fraud - This is where the staff or officials charged with the responsibilities of managing the scheme engage in fraudulent acts, such as creating fictitious pensioners and/or beneficiaries and making pension payments to themselves through the accounts of such fictitious pensioners. Others include: Employer Fraud, and Trust Busting (Pension Liberation).

In furtherance of the foregoing, ACCA (2003) provides good examples of frauds within identifiable pension schemes, such as: Misappropriation (of funds and assets); Non-payment of contributions by the employer; Borrowing by the employer. This could be done directly or through using assets as collaterals for borrowing; Buying or selling of assets by trustees without the required mandate or authority.

\section{Motivations for Fraud}

According to KPMG (2005), fraud risk in pension schemes is not likely to be driven by the dire need to attain certain financial targets, but rather for personal financial gain. Such motivations as observed by CIMA (2009) are typically based on greed. Personality and temperament are the likely motivations for fraud generally, and pension frauds in particular. CIMA (2009) also observed that individuals might be tempted, especially when confronted with ruins and predicaments beyond their immediate financial control. All such motivations for fraud are generally not different from what is obtainable as regards occupational fraud, which pension fraud stands as a notable example of. In this light, experts (Osisioma, 2009; Okoye, 2016) have identified several motivations for occupational frauds and abuses to include a desire to live beyond one's means, an overwhelming craving for personal gains, an excessive personal debt, a proximate alliance with customers, a poor pay compared to the job schedule, an uncontrollable desire for gambling and other social activities, undue pressure from the family and peers, etc.

\section{The Theoretical Framework}

The Theory of Differential Association (DAT) provides an appropriate theoretical base for this study. DAT was developed by Edwin H. Sutherland in order for him to explain why individuals commit various crimes/fraud (Sutherland, 1939). The basic assumption in this theory is that by interacting with others, people tend to appreciate and learn the attributes, values and techniques of, approaches to, and motivations for criminal behaviors. The Differential Association thus predicts that individuals are bound to choose or opt for criminal paths where the equilibrium of the definitions of misdemeanor or wrongdoing exceeds the balance of honesty or law abiding. Given the antecedents of pension frauds and scams in Nigeria, we observed that the motive/drive for such frauds/ scams may have been learnt through exposures and interactions with earlier culprits. The fact that the act is inborn to some is not overruled. More so, the arguments have been that the traits of pension frauds in the country were bred by the weaknesses or gaps inherent in the provisions of the PRA of 2004 and its subsequent revision/update in 2014. With the above, this study is driven by the tenets of DAT.

\section{An Empirical Review}

The studies of the PRA of 2004 and its subsequent revision of 2014 that led to the establishment of the Contributory Pension Scheme (CPS) abound. There are also studies of the various forms of fraud in the country, though with little emphasis on pension fraud, which is the crux of this study. In this section, the studies of the CPS and pension frauds/scams have been reviewed.

In a study by I. Omah, A. D. Anifowose and J. A. Ogundina (2013), an exploratory examination was done with respect to pension fraud and the supraadministrative system of pensions in the country. The survey method was used to obtain a public opinion through the questionnaires specifically designed for the purpose of the study. The analyses of the findings indicate, inter alia, the dominance of fraud managers in the acclaimed corridors of power. The researchers 
therefore called for the rehabilitation/restructuring of pension administration in Nigeria.

\section{A. S. Iyortsuun and K. T. Akpusugh (2013) explored} how the lifestyle of employees could effectively be managed after retirement. The data obtained from secondary and primary sources were sought. Through the survey design, the disproportional stratified method of sampling was employed to select the required sample of the study. The descriptive and inferential statistics were based on the results of the computed simple percentages and the chi-square $\left(X^{2}\right)$ statistical test for the hypothesis. The findings led to the conclusion that a myriad of challenges like fraud, corruption, inefficiency, governance, regulatory challenges, etc. had scuttled the success of the country's ongoing pension reform.

T. M. Fapohunda, (2013) conducted a study of the management of the pension systems in Nigeria by examining the attendant features and prospects vis$a$-vis the challenges of the existing schemes since they form the important aspects of retirement planning. Following the businographic design, the study relied on the data obtained from secondary sources (official publications, paper clippings and the documentations of the relevant agencies and authorities). Among other things, the findings were indicative of the fact that sharp practices like fraud had impinged the success of pension management and administration in the country, whereas, as he noted, for reforms in pension to be remarkable or successful, stakeholders would need to be sincere and committed to the objectives of the reform agenda of pension schemes.

By employing a survey design, E. Nwagwu, (2014) examined how the new CPS could be managed through transparency/accountability. The study specifically sought to know whether transparency/ accountability was maintained in managing the consolidated pension fund evident in the new CPS. In total 478 questionnaires were administered in the south-eastern part of the country to the employees and pensioners of Federal Universities, Pension Funds Custodians (PF.Custods), Pension Funds Administrators (PF.Admins) and the officials of the
National Pension Commission (PENCOM), who had randomly been selected for the study. Based on their specific objectives, the hypotheses were formulated and tested by the student T-test statistics. Overall, the findings indicated that until then, in managing pension funds, transparency/accountability had been maintained by the administrators and custodians of pension funds in Nigeria. The study, therefore, recommends that, among other things, licensed operators should ensure that all pension funds are insured so as to guarantee safeguard in the case of an economic crash.

O. I. Eme, O. A. Uche and I. B. Uche (2014b) did research in the popular police pension scam that was investigated by the Senate of the Federal Republic (Nigeria). The study specifically sought to detail the background information about the scam, the investigations and the findings. It discovered that debauched public officers massively laundered, embezzled, squandered and diverted public pension funds into accounts of private individuals and their associates without being indicted and/or halted. The researchers thus suggest a reversion to the earlier position of keeping the pension funds of MDAs with the $\mathrm{CBN}$ in order to minimize the recurrent abuse of such funds by pension officials through unauthorized lodgments with deposit money banks.

\section{METHODS}

The survey method is the method adopted in this study. The study's population consists of 435 accountants, auditors, finance officers, pensioners, the members of the personnel/officers of PENCOM, the officials/administrators and custodians of pension funds and the officials/civil servants of the selected institutions/establishments in Anambra State, Nigeria. The sample size was determined by using the Taro-Yamane method of the sample size determination and a sample size of 417 was calculated for the study. The data utilized were basically those assembled from a primary source through a wellstructured questionnaire, designed by applying the 
conventional 5-point Likert scale. The assembled data were collated, presented and analyzed via descriptive statistics (tables, percentages, and frequencies) and inferential statistics (the test of the hypotheses). The statistical technique adopted in testing all the formulated hypotheses was the Multiple Regression Analysis with the aid of Minitab Version 17. The acceptable hypothesis is that in which $\mathrm{R}^{2}$ (the coefficient of determination) lies between ninety five to one hundred percent (95-100\%), and vice versa.

\section{RESULTS AND DISCUSSION}

In this section, the results obtained after having tested the hypotheses were presented together with the relevant discussions.

\section{The Test of the Hypotheses}

In testing the formulated hypotheses in this study, the general model for multiple regression analysis was followed as stated below:

\section{General Regression Analysis: Yield (Y) versus $X 1, X 2, X 3$}

Hypothesis One - Regression Model:

Yield $(Y)=-33.4147+1.05808$ X1 - 1.36237 X2 + 1.72301 X3

Table 1 Summary of Model

R-Sq $=91.19 \%$ R-Sq(adj) $=90.34 \% \rightarrow$ R-Sq(pred $)=-54.58 \%$

Source: Authors, the result output from Minitab Ver. 17

The indications accounted for in Table 1 reveal that $\mathrm{R}^{2}$ was $91.19 \%$ (Adj $\mathrm{R}^{2}=90.34 \%$ ), meaning that the independent variables have a below 95\% explanatory ability of explicating the behavior of the dependent variable. Similarly, the F-Value in the regression model is 13.4719, whereas the F-Values for the independent variable were $18.5827,1.0640$ and 1.0738 , respectively (Table 2).
Table 2 Analysis of Variance (ANOVA)

\begin{tabular}{l|rrrrrc}
\hline Source & DF & Seq SS & Adj SS & Adj MS & \multicolumn{1}{c}{ F } & \multicolumn{1}{c}{ P } \\
\hline Regression & 3 & 42454.4 & 42454.4 & 14151.5 & 13.4719 & 0.197047 \\
X1 & 1 & 41282.2 & 19520.0 & 19520.0 & 18.5827 & 0.145115 \\
X2 & 1 & 44.2 & 1117.6 & 1117.6 & 1.0640 & 0.490136 \\
X3 & 1 & 1128.0 & 1128.0 & 1128.0 & 1.0738 & 0.488666 \\
Error & 1 & 1050.4 & 1050.4 & 1050.4 & & \\
\hline Total & 4 & 43504.8 & & & & \\
\hline
\end{tabular}

Source: Authors, the Results of the Analyzed Field Survey Data (2015) by using Minitab Ver. 17

Furthermore, given the regression model, since the coefficient of determination $\left(\mathrm{R}^{2}\right)$ of the variance is $91.19 \%<95 \%$, the conclusion is that the provisions of the PRA may not have reduced to a significant extent the motive for perpetrating pension fraud in Nigeria. This is more visible in the p-values of 0.197047, $0.145115,0.490136$ and 0.488666 , respectively (Table 2), which in all of the cases is greater than 0.05 . With this result, the alternate hypothesis is rejected, whereas the null hypothesis implying that the provisions of the PRA may not have reduced to a significant extent the motive for perpetrating pension fraud in Nigeria is accepted.

Hypothesis Two - Regression Model:

Yield $(Y)=11.7215+1.139$ X1 -0.851003 X2 + 0.565115 X3

Table 3 Summary of Model

$\mathrm{R}-\mathrm{Sq}=91.83 \% \mathrm{R}-\mathrm{Sq}(\mathrm{adj})=91.31 \% \rightarrow \mathrm{R}-\mathrm{Sq}(\mathrm{pred})=-66.73 \%$

Source: Authors, the result output from Minitab Ver. 17

The suggestions presented in Table 3 bring to light the fact that $\mathrm{R}^{2}$ was $91.83 \%$ (Adj $\mathrm{R}^{2}=91.31 \%$ ), meaning that the independent variables have a below $95 \%$ explanatory ability of explicating the behavior of the dependent variable. Similarly, the F-Value in the regression model is 15.0143, whereas the F-Values for the independent variable were 2.2267, 0.0362 and 0.0206, respectively (Table 4). 
Table 4 Analysis of Variance (ANOVA)

\begin{tabular}{l|rrrrrc}
\hline Source & DF & Seq SS & Adj SS & Adj MS & \multicolumn{1}{c}{ F } & P \\
\hline Regression & 3 & 26451.5 & 26451.5 & 8817.18 & 15.0143 & 0.186960 \\
X1 & 1 & 26371.8 & 1307.6 & 1307.63 & 2.2267 & 0.375866 \\
X2 & 1 & 67.7 & 21.3 & 21.27 & 0.0362 & 0.880271 \\
X3 & 1 & 12.1 & 12.1 & 12.08 & 0.0206 & 0.909329 \\
Error & 1 & 587.3 & 587.3 & 587.25 & & \\
\hline Total & 4 & 27038.8 & & & & \\
\hline
\end{tabular}

Source: Authors, the Results of the Analyzed Field

Survey Data (2017) by using Minitab Ver. 17

Furthermore, given the regression model, since the coefficient of determination $\left(\mathrm{R}^{2}\right)$ of the variance is $91.83 \%<95 \%$, the conclusion is that Pension Fund Assets (PFAs) may not have been adequately diversified into profitable investment opportunities in Nigeria. This is more visible in the p-values of $0.186960,0.375866,0.880271$ and 0.909329 , respectively (Table 4), which in all of the cases is greater than 0.05 (sig. level). With this result, the alternate hypothesis is rejected, whereas the null hypothesis that PFAs are not adequately diversified into profitable investment opportunities is accepted.

Hypothesis Three - Regression Model:

Yield $(Y)=-1.14617+0.352241 X 1+0.486815 X 2+$ $0.175307 \mathrm{X} 3$

Table 5 Summary of Model

$\mathrm{R}-\mathrm{Sq}=85.85 \% \mathrm{R}-\mathrm{Sq}(\mathrm{adj})=83.39 \% \rightarrow \mathrm{R}-\mathrm{Sq}(\mathrm{pred})=-699.60 \%$

Source: Authors, the result output from Minitab Ver. 17

The Table 5 reveals an $\mathrm{R}^{2}$ of $85.85 \%$ (Adj $\mathrm{R}^{2}=83.39 \%$ ), meaning that the independent variables have a below 95\% explanatory ability of explicating the behavior of the dependent variable. Similarly, the F-Value in the regression model is 7.69386, whereas the F-Values for the independent variable were $0.21303,0.44607$ and 0.07492, respectively (Table 6).
Table 6 Analysis of Variance (ANOVA)

\begin{tabular}{|c|c|c|c|c|c|c|}
\hline Source & DF & Seq SS & Adj SS & Adj MS & $\mathrm{F}$ & $\mathrm{P}$ \\
\hline Regression & 3 & 13153.0 & 13153.0 & 4384.32 & 7.69386 & 0.257651 \\
\hline$X_{1}$ & 1 & 12555.4 & 121.4 & 121.39 & 0.21303 & 0.724714 \\
\hline$X_{2}$ & 1 & 554.9 & 254.2 & 254.19 & 0.44607 & 0.625128 \\
\hline$x_{3}$ & 1 & 42.7 & 42.7 & 42.69 & 0.07492 & 0.829916 \\
\hline Error & 1 & 569.8 & 569.8 & 569.85 & & \\
\hline Total & 4 & 13722.8 & & & & \\
\hline
\end{tabular}

Source: Authors, the Results of the Analyzed Field Survey Data (2017) by using Minitab Ver. 17

Furthermore, given the regression model, since the coefficient of determination $\left(\mathrm{R}^{2}\right)$ of the variance is $85.85 \%<95 \%$, the conclusion is that the anti-fraud measures provided by the PRA may not have been effective in significantly reducing pension fraud in Nigeria. This is more evident in the p-values of $0.257651,0.724714,0.625128$ and 0.829916 , respectively (Table 6), which in all of the cases is greater than 0.05 (sig. level). With this result, the alternate hypothesis is rejected, whereas the null hypothesis that the antifraud measures provided by the PRA may not have been effective in significantly reducing pension fraud in Nigeria is accepted.

\section{CONCLUSION}

The study of the anatomy of pension fraud in Nigeria $\mathrm{x}$-rays the concept of pension and pension fraud/scam and analyzes the various fraud schemes perpetrated against the pension scheme in Nigeria. The efforts were devoted to finding probable reasons for such fraudulent schemes and the manners in which pension fraud could be curtailed through the effective management of pension funds. By adopting the survey design, the data obtained were accordingly subjected to analysis and the results were very revealing. From the analyzed data and the reviewed literature, it was observed that the existing pension schemes in Nigeria may not have proven to be successful due to 
the rampant and alarming cases of pension fraud that have remained non-grasped to date.

The outcome of this study has thus contributed to knowledge by proving that fraud has consistently remained a bottleneck to efficiency in the management of pension funds in Nigeria. Most importantly, it was observed that, despite the much canvassed efforts of several Nigerian Governments in reforming the pension schemes and their subsequent revisions in the country, the provisions of the current PRA may not have significantly reduced the intent/motive for fraud in the management/administration of pensions in Nigeria. Sadly, public officials engaged by the Federal Government to fight pension fraud in the process have grossly involved themselves in various pension scams involving billions of naira. The situation is consequent upon the fact that the anti-fraud measures/provisions stipulated in Nigeria's PRA are not strong enough to reduce an increasing and incessant level of pension fraud in the country.

Interestingly, the evidence obtained from the test of the hypotheses further reveals that PFAs have not been judiciously diversified into other investment alternatives yet, although the provisions of the PRA envisage that pension funds' assets belong to investable assets. Though the effective management of pension funds may not be an easy task to perform, the officials involved in such management are expected and ought to be rational decision-makers and managers. When not properly invested, the perils of fraud are bound to exist. More so, where the existing and potential motivating factors are not dealt with, pension fraud persists. Therefore, if fraud is reduced or even eliminated from the process of managing pension funds, Nigeria will have a good pension scheme of her dream.

This study, however, is limited by the scope, as the analysis carried out was based on the primary data obtained from the stakeholders in the south-eastern part of the country. In view of this, we suggest that future researchers should attempt to synergize with the National Bureau of Statistics (NBS) and the other relevant statutory bodies so as to obtain secondary data on a broader scope. By means of multivariate and correlation analyses, efforts could be made to determine the magnitude of pension fraud in Nigeria and thus establish whether there is a correlation between the management of pension fraud, the PRA and a reduction and/or increase in the cases, the amounts and the magnitude of pension fraud/scam in the country as a whole.

The following recommendations have been put forth:

- Additional provisions and subsequent revisions must urgently be added and made, respectively, to the existing PRA. Such provisions and/or revisions must specifically be tailored for the purpose of reducing to a significant extent the opportunities and drivers of pension frauds by instituting severe punitive measures for culprits. The provisions should also be able to reduce to a significant extent the intent for committing pension fraud, while simultaneously inculcating moral ethics among public servants in Nigeria.

- Administrators (PF.Admins) and Custodians (PF.Custods) tasked with the management of pension funds are thus encouraged to be rational investors in their investment decisions concerning PFAs by investing in different portfolios that are worthwhile to invest in, as an adequate diversification of PFAs into profitable investment opportunities will minimize the risk of PFAs exposure to fraud.

- Since the current anti-fraud measures have not successfully reduced pension fraud to a significant extent, it is thus suggested that PENCOM should again recommend the National Assembly to pass into law the implementation of additional anti-fraud punitive measures, such as life imprisonment, outright killing, the permanent denial/refusal of the right to any political position and permanent banishing from oversea vacations and travelling, as these will bring about fraud reduction and will also serve as a deterrent against potential pension fraudsters. 


\section{REFERENCES}

ACCA. (2003). The Audit of Occupational Pension Schemes. Technical Factsheet 62.

Adeniji, A. A., Akinnusi, D. M., Falola, H. O., \& Ohunakin, F. (2017). Administration of retirement benefits in Nigeria: Periscoping the effect on retirees. International Journal of Applied Business and Economic Research, 15(17), 255-269.

Agbedo, O. (2017). Pension Fraud: Maina's dirty deals. The Sun, October, 29, 2017. Retrieved December 8, 2017, from http://sunnewsonline.com/pension-fraud-mainas-dirtydeals/

Akinkiotu, E., \& Onuba, I. (2016). Pension: EFCC arrests suspended DG, others for N2.5bn fraud. The Punch Newspaper, Retrieved December 8, 2017, from http:// punchng.com/pension-efcc-arrests-suspended-dg-othersfor-n2-5bn-fraud/

allAfrica.com (2012). Nigeria: Pension scam-N273 billion looted in six years. Retrieved December 8, 2017, from http:// allafrica.com/stories/201206210904.html

Auditing Practices Board (APB). (2011). The audit of occupational pension schemes in the United Kingdom. Practice Note 15.

Awom, U. (2012). Pension fund fraud: Senate report indicts Maina, Banks, others. Retrieved August 12, 2013, from http://www.nigerianbestforum.com/blog/pens.

CIMA. (2009). Corporate Fraud. Gateway Series, No. 57.

Davis, E. (1993). The structure, regulation and performance of pension funds in Nine industrial countries. Policy Research Working Papers, No.1229.

Demola, Y. (2008). Pension Reform and the fate of Nigerian workers. Retrieved December 8, 2017, from http://www. socialistnigeria.org/print.php?text $=1345$

Eme, O. I., Uche, O. A., \& Uche, I. B. (2014a). Pension Reform Act 2014 and the future of pension administration in Nigeria. Arabian Journal of Business and Management Review, $4(2), 156-165$.

Eme, O. I., Uche, O. A., \& Uche, I. B. (2014b). An analysis of police pension fraud and the future of pension administration in Nigeria. Kuwait chapter of Arabrian Journal of Business and Management Review, 4(1), 495-513.
Fapohunda, T. M. (2013). The pension system and retirement planning in Nigeria. Mediterranean Journal of Social Sciences, 4(2), 25-34. doi:10.5901/mjss.2013.v4n2p25

Iyortsuun, A. S., \& Akpusugh, K. T. (2013). Effective management of life after retirement and its impact on retirees from the public service: A case study of Benue State, Nigeria. Global Journal of Management and Business Research, 13(5), 1-7.

KPMG (2005). Pension scheme fraud risk. Frontier in finance, Issue 35, KPMG.

Mesike, G., \& Ibiwoye, A. (2012). Pension reform and financial market development nexus: Evidence from Nigeria. International Journal of Academic Research in Business and Social Science, 2(6), 574-586.

Nenyiaba, I. C., \& Okoye, E. I. (2015). Evaluation of key determinants of fraud free financial report: A focus on Nigeria. Business and Management Studies, 1(2), 20-35.

Nwagwu, E. (2014). Transparency and accountability as security mechanisms in the management of the new contributory pension scheme in Nigeria. Public Policy and Administration Research, 4(2), 20-30.

Nweke, J. O. (2015). Post-retirement stress under noncontributory pension regime: A study of retired civil servants in Ebonyi State Nigeria. Canadian Social Science, 11(6), 109-117. doi:10.3968/7106

Odia, J. O., \& Okoye, A. E. (2012). Pension reform in Nigeria: A comparison between the old and the new scheme. Afro Asian Journal of Social Sciences, 3(3),1-17.

Ogwumike, F. O. (2008). Prospects and challenges of the 2004 pension reform scheme in Nigeria: Some lessons from the Chilean experience. CBN Bullion, 32(2), 3-16.

Okoye, E. I. (2016). Anatomy of Fraud and corruption in Nigeria: A search for the Pandora box and panacea. The $32^{\text {nd }}$ Inaugural Lecture of The Nnamdi Azikiwe University, Awka, Anambra State. Awka, Nigeria: Nnamdi Azikiwe University.

Okoye E. I., \& Akenbor, C. (2009). A critical analysis of the fraud triangle for sustainable development in Africa. The University Advanced Research Journal, 1, 1-13. 
Okoye, E. I., Okafor, T., \& Ijeoma, N. B. (2009). Impact of fraud triangle on audit process: The Nigerian accountants' view. The University Advanced Research Journal, 1, 130-145.

Olayinka, K. B. (2010). The Nigerian pension system: Reform and expectations. Pensions: An International Journal, 15(1), 3-10.

Omah, I., Anifowose, A. D., \& Ogundina, J. A. (2013). Pension Fraud: A concomitant debacle in public sector economy Nigeria perspective. Journal of Business Management $\&$ Social Sciences Research, 2(4), 8-14.

Onyeonoru, I. P., Matthew, E. E., \& David, I. (2013). Social policy and the retrenchment of the welfare state in Nigeria: The old and new pension schemes and lessons from the Nordic model. Journal of Developing Country Studies, 3(10), 31-39.

Osisioma, B. (Ed), (2009). Fraud management and forensic accounting. The Nigerian Accountant, a publication of National Accountants of Nigeria (ANAN).
Owojori, A. (2008). Nigeria: Risk management in pension fund administration in Nigeria. Un Published, Retrieved December 8, 2017, from http://www.mondaq.com/ Nigeria/x/68466/retirement+superannuation+plans +pensions +schemes/Risk+Management+In+Pension+Fund +Administration +In +Nigeria

Sipe, S. R., Metrejean, C. T., \& Donaldson, W. (2015). Defined benefit pension fraud: A ticking time bomb. Journal of Forensic and Investigative Accounting, 2(2), 176-194.

Sutherland, E. (1939). Principles of Criminology. Chicago, Philadelphia: J. B. Lippincott Company.

Tasker, K. (2012). Is Fraud Really an Issue for Pension Schemes? A Publication of Baker Tilly International.

The Pensions Regulators. (2015). Pension Scams. Don't Get Stung. Action Pack for Trustees and Administrators.

Vasiu, L., Warren, M., \& Mackay, D. (2003, July). Defining fraud: Issues for organizations from an information systems perspective. Proceeding of the 7th Pacific Asian Conference on Information Systems (971-979), Adelaide, South Australia.

Received on $8^{\text {th }}$ December 2017, after revision, accepted for publication on $22^{\text {nd }}$ December 2017. Published online on $29^{\text {th }}$ December 2017.

Amaka Elizabeth Agbata is an Associate Chartered Accountant (ACA). She works at the Bursary Unit, Nnamdi Azikiwe University, Nigeria. She is currently a PhD student at the Department of Accountancy, Nnamdi Azikiwe University.

Chizoba Marcella Ekwueme is a Professor of Accounting at Nnamdi Azikiwe University, Awka, Nigeria, where she started her academic career in 1994. She is a fellow of ANAN (Nigeria), and a certified member of other notable professional bodies.

Edirin Jeroh, Ph. D., is a Senior Lecturer at the Department of Accounting of Delta State University, Abraka, Nigeria. He is an associate member of ICAN (Nigeria) and a prolific writer, who has published several research outcomes in reputable national and international journals. 


\title{
ANATOMIJA PREVARA U PENZIONIM FONDOVIMA U NIGERIJI: NJIHOVI MOTIVI, UPRAVLJANJE I BUDUĆNOST SISTEMA PENZIONOG OSIGURANJA U NIGERIJI
}

\author{
Amaka E. Agbata', Chizoba M. Ekwueme'1 i Edirin Jeroh² \\ 'Department of Accountancy, Nnamdi Azikiwe University, Awka, Anambra State, Nigeria \\ Department of Accounting, Delta State University, Abraka, Delta State, Nigeria
}

\begin{abstract}
Ovom studijom utvrđeno je na koji bi način upravljanje Sistemom penzionog osiguranja u Nigeriji moglo biti podignuto na viši nivo uspostavljanjem efektivnog menadžmenta, čime bi se smanjila praksa vršenja prevarnih radnji, koje su prisutne u tom sistemu. Sledeći pravilo bibliotečkog istraživanja putem ankete razviena je petostepena Likertova skala u cilju izvođenja primarnih informacija o stvarima koje se tiču penzionog osiguranja, na uzorku od 435 ispitanika. Prikupljeni podaci su predočeni i analizirani. Formulisane su i testirane tri hipoteze na osnovu modela višestruke regresione analize, uz pomoć Minitab verzije 17. Nalazi pokazuju da, uprkos odredbama Zakona (Zakon o reformi penzionog osiguranja ZRPO), nije došlo do značajnog smanjenja izvršenja prevarnih radnji u penzionim fondovima. Nije sprovedena ni adekvatna diversifikacija akumuliranih sredstava iz penzionih fondova, koja bi se usmerila ka profitabilnim investicionim alternativama. $S$ toga je, između ostalog, preporučeno da bi zajedničkim snagama trebalo izvršiti dopune ZRPO, barem da bi se obeshrabrili počinioci prevarnih radnji u penzionim fondovima u svojoj nameri da iste izvrše, uvođenjem oštrih kaznenih mera za počinioce, uz istovremeno usađivanje etičkih načela među državnim službenicima u Nigeriji.
\end{abstract}

Ključne reči: Komisija za dodelu nacionalnih penzija, penzioni fondovi, prevare u penzionim fondovima, Zakon o reformi penzionog osiguranja, upravnici i staratelji penzionih fondova

JEL Classification: G23, G28, H55 